\title{
Green areas in Białystok
}

\author{
Agata Łochnicka \\ https://orcid.org/0000-0000-0000-0000 \\ agata.lochnicka@wp.pl
}

Bialystok University of Technology

\section{Jolanta Niedzielko}

https://orcid.org/0000-0000-0000-0000

j.niedzielko@pb.edu.pl

Department of Agri-Food Engineering and Environmental Management, Bialystok University of Technology

\begin{abstract}
Summary: This work contains a description of four housing estates in Białystok from different decades of the $20^{\text {th }}$ century. The approximate percentage of green areas in these states was determined based on available sources. Existing development plans were analysed with a view to the records regarding greenery. Own observations allowed to define the state of green areas - their functions, accessibility, quality and relation to space. The results of the analysis made it possible to discuss the observed problems and indicated the ways to solve them.
\end{abstract}

Key words: housing development, green area, local development plan, sustainable development, biologically active area, site summary

\section{Introduction}

There are numerous definitions of urban green areas. Most often it is understood as the general vegetation within the city limits and housing structures, which arose as a result of planned human action, taking into account the natural greenery present in the area. It is classified in various ways, in terms of functions, structure or accessibility.

Urban green areas are important elements of the city. They also perform numerous natural, social, economic, cultural and aesthetic functions. They have a positive effect on the climate and sanitary conditions as areas of air regeneration and exchange, suppress noise, shield from smoke and dust, bind carbon dioxide, has antibacterial effects and ionize the air [Banaszak, Izdebska, 1995]. They are an important component of the space planning process, introducing variety, contrasting with the architecture or emphasizing the forms [Zachariasz 2006]. They also become a place of recreation and social integration [Degórska 2004]. The New Charter of Athens emphasizes that "maintaining a possibility of contact with natural elements is not only a source of well-being, but also a prerequisite for survival", also notes that "environmental quality is a major factor in guaranteeing the economic success of a city - it also contributes to social and cultural vitality" [The New Charter of Athens, 2003]. The standards of the World Health Organization indicate that the minimum area of green areas per one inhabitant should be 50 square meters. Moreover, the European Commission emphasizes the importance of the role that greenery plays in the process of sustainable urban development. This is particularly noticeable in the countries of Western Europe, where post-industrial areas are often transformed into green forms of high value as part of urban regeneration [Asani 2007].

It can be easily noticed that the need of green areas is used advantageously by various economic entities. For example, developers in Gdańsk add the word "Park" to their new housing estates' names, e.g. Alfa Park, Central Park, Chmielna Park, City Park, Gdańsk Myśliwska Park, Jodłowy Park, Neptun Park, Oliwa Park 
[Korwel-Lejkowska, Topa 2017]. The names of two Białystok housing estates: Zielone Wzgórza ('Green Hills') and Leśna Dolina ('Forest Valley') can also prove this. Without a doubt, greenery significantly affects the way we see a modern city and its elements; it even becomes its showcase [Godzina 2015; Sutkowska 2006]. It is emphasized that in the face of the progressing urbanization and transformation of the urban landscape, greenery is a means of protecting man and his living environment [Oleksiejuk 2005]. The impact of green areas on the reduction of the cost of communal services, the development of the local economy and improvement of the quality of life of residents is also significant [red. Berghöfer 2011]. The presence of more arranged green areas translates into greater potential for shaping the functional and spatial structure of the city [Godzina 2015]. In addition, public space (of which green areas are one type) of high aesthetic quality makes people want to stay in it longer and establish social contacts more willingly [Gehl 2009]. It is also noteworthy that the quantity and quality of urban greenery can be one of the indicators of sustainable development [Mierzejewska 2004].

For the purpose of this study, four housing estates in Białystok built in different time frames were selected: Piaski (1970s), Słoneczny Stok (1980s), Zielone Wzgórza (1990s) and Nowe Miasto (developing since the late 1980s to the present). The local plans were analyzed for greenery records, greenery calculations were made based on publicly available orthophotomaps and vector data and own field observations were carried out. The obtained diagnosis of the current state of greenery in these estates - its main functions, quality, accessibility and connection with space - allowed to indicate the biggest problems and the ways to solve them.

\section{Characteristics of residential green areas in Bialystok on the example of selected housing estates}

The Piaski Housing Estate was established in the 1970s following the project of the Zakład Projektowania Inwestycyjnego "Inwestprojekt" in Białystok. The main designer was mgr inż. arch. Danuta Łukaszewicz [SM Piaski website, access 30/05/2019]. In 2004, the estate was combined with Osiedle Tysiąclecia, which is in turn a clear example of a self-sufficient housing estate. Its construction began in 1959 with the thought of both residential buildings and social infrastructure, e.g. shops, nurseries and kindergartens. To this day, Piaski and Osiedle Tysiąclecia are considered the most thought-out and best implemented investments in the city. The presence of ore green areas compared to other housing estates in Białystok can be noticed [Kłopotowski 2016]. The only drawback is the fact that the designer of this estate, arch. Marian Najmowicz, did not foresee the need for more parking areas - at the time (1960s), the cars were quite rare in Poland, so nowadays green areas are being adapted for car parks.

Although currently Piaski and Osiedle Tysiąclecia are again separate units, even on official city portals it is still shown that Osiedle Tysiąclecia is part of Piaski. Therefore, for the purposes of the analysis, these estates were treated as a coherent whole.

There are two local spatial development plans in this area - MPZP części osiedla Piaski w Biatymstoku (rejon ul. Mazowieckiej i Żelaznej) from 2011 and MPZP części osiedla Piaski w Białymstoku (rejon ul. M. Curie-Skłodowskiej i Legionowej) from 2019. These plans contain both typical entries (determination of the share of biologically active area and designation of arranged green areas) and more precise ones, indicating the nature of the estate (preservation and development of green areas, preservation of the biologically active surfaces around trees, as well as an order to plant at least one tree for each cut down within a building plot and at least one tree for 5 parking spaces within the parking lot or at its borders). There are no plans regarding only the greenery, and a separate company is responsible for maintaining it within the estate. It is also worth mentioning that there is a natural monument established on October 29th, 2016 - pedunculate oak Quercus robur that is over two hundred years old, 23,50 m high and with trunk circumference of $326 \mathrm{~cm}$ measured at a height of $130 \mathrm{~cm}$ [GDOS, access 27/04/2019].

Słoneczny Stok was established in the 1980s. Its designers, Jan Citko and Janusz Dmowski, paid special attention to the terrain layout, making the use of space dependent on it [Kłopotowski 2016]. There are 3 local spatial development plans in the estate:

- Zmiana MPZP części rejonu administracyjnego Starosielce-Marczuk (rejon ulicy Szarych Szeregów) from 1997;

- MPZP części osiedla Stoneczny Stok w Białymstoku (rejon ul. W. Witosa) from 2004; 
MPZP części doliny rzeki Bażantarki (odcinek w rejonie Stawów Marczukowskich i ul. ks. Jerzego Popiełuszki w Biatymstoku from 2010.

In the first of these documents, there is a record about the need of developing at least $25 \%$ of the area as the housing estate green (defined as: 'lawns, woodlands and bushes, playgrounds for children and places of everyday rest'). The records of the next document mention greenery only in the form of a ban (a ban on planting trees and plants with extensive root systems in the technical infrastructure area). The last document is different, as it regards the valuable natural area of the Bażantarka river valley. It imposes several obligations: maintaining the continuity of spatial connections within the natural system and the biological housing of the river bed, protection of the open waters, shaping biologically active natural floodwaters due to the renaturalization of Stawy Marczukowskie and the banks of the Bażantarka river bed. It also bans introduction of vegetation incompatible with habitat conditions, plantings that divide the river valley transversely and activities that could potentially harm the environment. There are no plans regarding only the greenery, and a separate company is responsible for maintaining it within the estate.

Zielone Wzgórza was established in the early 1990s. Two local spatial development plans are in force there - the already mentioned Miejscowy plan zagospodarowania przestrzennego części doliny rzeki Bażantarki (odcinek w rejonie Stawów Marczukowskich i ul. Ks. J. Popietuszki) w Biatymstoku and Miejscowy plan zagospodarowania przestrzennego części osiedla Zielone Wzgórza w Biatymstoku from 1997. The latter one, the oldest such document in Białystok, was drawn up for the planned investment (current Galeria Zielone Wzgórze, construction of which began in 2006). It claimed that the original vegetation cover should be kept until its implementation and the future greenery was to fulfill only decorative and - along the communication routes - protective functions. However, its share in the entire area was not determined. Given the specifics of the estate (the lack of larger green areas, squares or parks), this was not a particularly apt move. There are no plans regarding only the greenery, and a separate company is responsible for maintaining it within the estate.

The last of the examined units is Nowe Miasto. Its construction began at the end of the 1980s. Nowadays, it is the most densely populated housing estate in Bialystok, neighbouring the rapidly developing village of Kleosin and Krywlany airport [Portal Białystok Online, access 12/02/2019]. There are 6 local spatial development plans in its area:

- Zmiana MPZP części osiedla Nowe Miasto w Białymstoku (rejon ul. Zapiecek) - 1997;

- MPZP części osiedla Nowe Miasto w Białymstoku (rejon Al. I. J. Paderewskiego) - 2006;

- MPZP części osiedla Nowe Miasto w Biatymstoku (w rejonie ulic: K. Putaskiego i Transportowej) - 2006;

- MPZP części osiedla Nowe Miasto w Białymstoku (w rejonie ulic Ścianka, Starosielce i P. Łodzińskiego) - 2006;

- MPZP części osiedla Nowe Miasto w Biatymstoku (w rejonie ulic Putaskiego, Stawińskiego i Wiadukt) - 2008;

- MPZP części osiedla Nowe Miasto w Białymstoku (w rejonie ulicy Składowej) - 2010.

The first document does not mention greenery at all. The next one contains information on allocating 29 hectares of agricultural land for non-agricultural purposes and 0,5 hectare of forest land for non-forest purposes (i.e. for new residential and service buildings). Further records impose the necessity of allocating part of the area for insulation green areas and leaving the existing forest to serve as public and recreational greenery. They also require that the watercourse valley along Aleja J. J. Paderewskiego shall be preserved in its natural and semi-natural state. However, no records mention the required minimum share of biologically active surfaces in the housing estates.

MPZP części osiedla Nowe Miasto w Białymstoku (w rejonie ulic: K. Pułaskiego i Transportowej mentions the allocation of 8,9 hectares of agricultural land for other purposes. Unlike the previous document (notabene, passed on the very same day), it contains more detailed records regarding greenery. For example, it requires maintaining a minimum of $40 \%$ share of biologically active surfaces in the areas intended for education buildings, $30 \%$ in the areas intended for religious buildings and housing estates with service buildings. It should be noted that these values are higher than the ones in different local development plans in force in Białystok.

Another of the analysed documents also specifies the minimum share of biologically active surfaces for different zones, just like the previous plan. In addition, it imposes the obligations to preserve the existing stand of noble species with a breast height diameter exceeding $30 \mathrm{~cm}$, to maintain the biological housing and the 
open nature of the Bażantarka watercourse, and - regarding the construction of car parks - to introduce high greenery in the proportion of at least one tree for five parking spaces.

The fifth analyzed local plan sets similar proportions for the biologically active surfaces. It also indicates the area designated for public greenery with a recreational function, ordering the preservation of the existing stand and the structure of the vegetation cover. Moreover, the document enforces maintaining the continuity of spatial connections of the Horodnianka river valley and other biologically active areas through biological maintenance of the river housing and its open nature. It also imposes the obligation to create dense multi-stage greenery strips along Aleja I. J. Paderewskiego, especially in the vicinity of residential and service buildings, and allotment gardens. Additionally, it requires the introduction of high greenery - a minimum proportion of one tree for five parking spaces.

\section{GREEN AREAS IN BIAŁYSTOK}

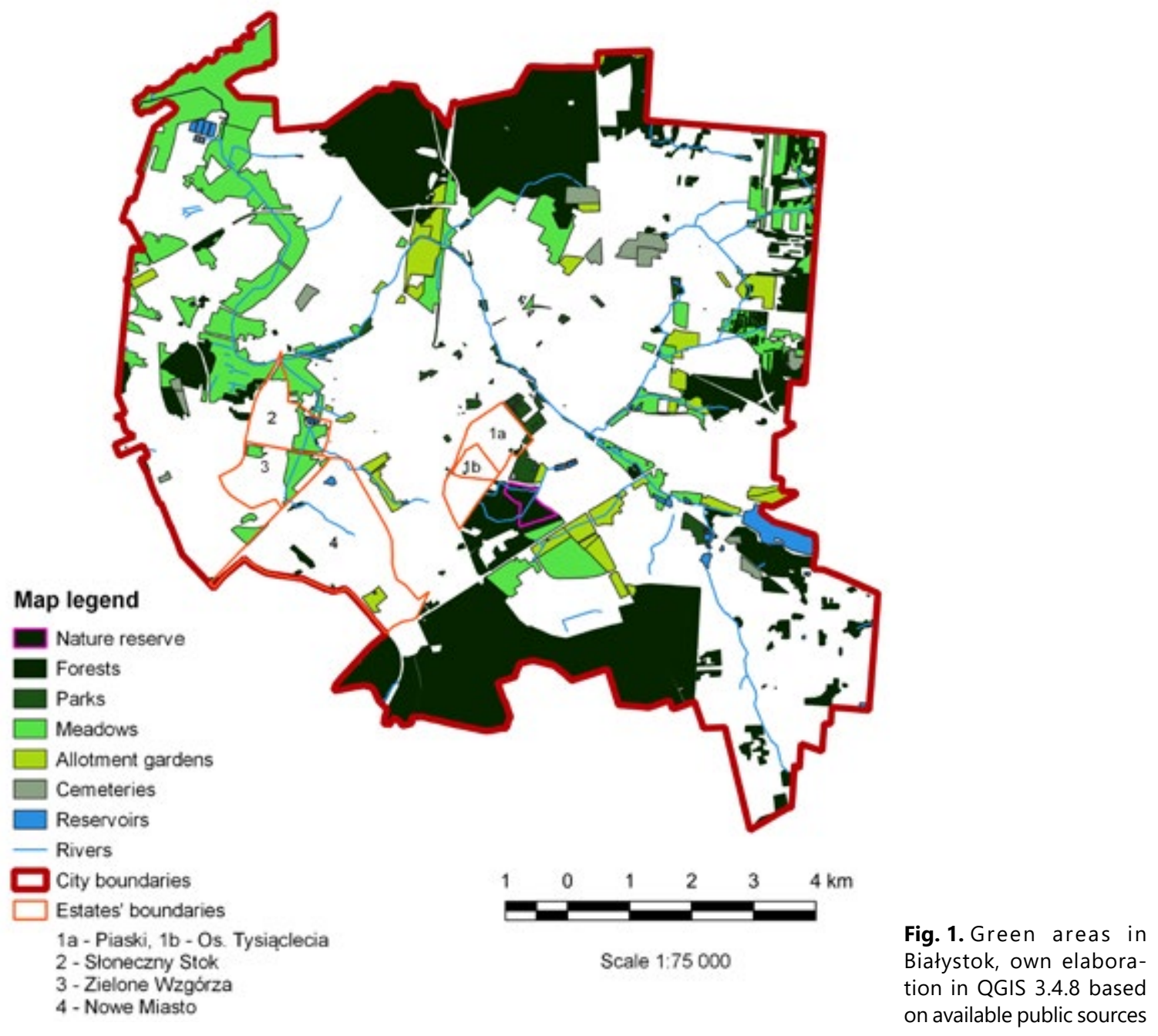

The last of the examined documents requires: the preservation of the existing watercourse in the form of an open ditch with the biological casing of the banks, the maintenance of the existing stand and the structure of the plant cover in the area designated for arranged greenery, and the use of undeveloped and unpaved surfaces for various forms of greenery with elements of landscape architecture. The records regarding the share of biologically active surfaces are identical to the ones in the other plans in force within this estate. There are no plans regarding only the greenery, and a separate company is responsible for maintaining it within the estate. 
Figure 1. shows the green areas in Bialystok and the borders of the examined estates. Table 1 presents the share of various types of the greenery in the chosen estates, calculated using available orthophotomaps and vector data. It should be noted, though, that only the areas with specific function were taken into account. The share of greenery understood as biologically active surfaces would be higher. The conclusions of the inventory carried out on April $24-26^{\text {th }}, 2019$ are presented in Table 2., while Table 3. lists the possible solutions of the observed problems.

Table 1. Share of individual types of green areas in the area of housing estates, own study

\begin{tabular}{|ccccc|}
\hline Estate & $\begin{array}{c}\text { Piaski and } \\
\text { Tysiąclecia }\end{array}$ & $\begin{array}{c}\text { Słoneczny } \\
\text { Stok }\end{array}$ & Nowe Miasto & $\begin{array}{c}\text { Zielone } \\
\text { Wzgórza }\end{array}$ \\
\hline Total area of the estate [hectare] & $\mathbf{1 3 3 , 4 1}$ & $\mathbf{1 0 8 , 7 8}$ & $\mathbf{3 8 9 , 3 8}$ & $\mathbf{1 1 4 , 0 4}$ \\
\hline Green area [hectare] & $\mathbf{2 1 , 2 1}$ & $\mathbf{4 1 , 8 0}$ & $\mathbf{4 8 , 7 5}$ & $\mathbf{4 5 , 3 7}$ \\
\hline Total greenery [\%] & $\mathbf{1 5 , 9 0}$ & $\mathbf{3 8 , 4 3}$ & $\mathbf{1 2 , 5 2}$ & $\mathbf{3 9 , 7 8}$ \\
\hline Forests and trees [\%] & 0,74 & - & 2,01 & 5,20 \\
\hline Parks and recreation areas [\%] & 0,54 & 2,95 & - & - \\
\hline Fields [\%] & - & 24,67 & - & 26,73 \\
\hline Allotments [\%] & - & - & 2,09 & - \\
\hline Playgrounds [\%] & 0,71 & 1,69 & 0,23 & 0,68 \\
\hline Military training fields [\%] & - & - & 6,72 & - \\
\hline Lawns [\%] & 7,15 & - & - & - \\
\hline Water tanks [\%] & - & 1,58 & 0,45 & - \\
\hline $\begin{array}{c}\text { Greenery accompanying } \\
\text { educational facilities [\%] }\end{array}$ & 1,32 & 2,57 & 0,29 & 2,15 \\
\hline routes [\%] & 5,44 & 4,97 & 0,73 & 5,02 \\
\hline
\end{tabular}

Table 2. Presence of green areas in housing estates

\begin{tabular}{|c|c|c|c|c|}
\hline Estate & $\begin{array}{l}\text { Piaski and } \\
\text { Tysiąclecia }\end{array}$ & Słoneczny Stok & Nowe Miasto & Zielone Wzgórza \\
\hline $\begin{array}{c}\text { Main } \\
\text { functions }\end{array}$ & $\begin{array}{c}\text { Recreational, } \\
\text { insulating, aesthetic }\end{array}$ & $\begin{array}{l}\text { Areas of great } \\
\text { natural value } \\
\text { (Bażantarka river } \\
\text { valley), recreational, } \\
\text { isolating and } \\
\text { aesthetic }\end{array}$ & $\begin{array}{l}\text { Insulating, productive } \\
\text { (allotments), other } \\
\text { (military areas) }\end{array}$ & $\begin{array}{c}\text { Valuable natural } \\
\text { areas (Bażantarka } \\
\text { river valley), isolating, } \\
\text { aesthetic }\end{array}$ \\
\hline Quality & $\begin{array}{l}\text { Good } \\
\text { (one park and other } \\
\text { ones neighbouring, } \\
\text { large share of high } \\
\text { greenery, presence } \\
\text { of old trees and } 1 \\
\text { natural monument) }\end{array}$ & $\begin{array}{c}\text { Rather good } \\
\text { (recreational areas } \\
\text { and valuable natural } \\
\text { areas, rich and } \\
\text { diverse decorative } \\
\text { greenery) }\end{array}$ & $\begin{array}{l}\text { Below the average } \\
\text { (no recreational } \\
\text { areas, neglect of } \\
\text { some areas) }\end{array}$ & $\begin{array}{c}\text { Average } \\
\text { (no recreational areas } \\
\text { but valuable natural } \\
\text { areas, rich and } \\
\text { diverse decorative } \\
\text { greenery) }\end{array}$ \\
\hline
\end{tabular}




\begin{tabular}{|c|c|c|c|c|}
\hline Estate & $\begin{array}{l}\text { Piaski and } \\
\text { Tysiąclecia }\end{array}$ & Słoneczny Stok & Nowe Miasto & Zielone Wzgórza \\
\hline $\begin{array}{l}\text { Connection } \\
\text { with space }\end{array}$ & $\begin{array}{l}\text { Good } \\
\text { (direct connection } \\
\text { with green areas } \\
\text { important for the } \\
\text { city, greenery filling } \\
\text { the space between } \\
\text { buildings) }\end{array}$ & $\begin{array}{l}\text { Rather good } \\
\text { (the presence } \\
\text { of recreational } \\
\text { areas, greenery } \\
\text { filling the space } \\
\text { between buildings, } \\
\text { enhancement of } \\
\text { buildings' aesthetical } \\
\text { values thanks to } \\
\text { decorative greenery) }\end{array}$ & $\begin{array}{l}\text { Below average } \\
\text { (greenery } \\
\text { accompanying } \\
\text { single-family } \\
\text { buildings as a } \\
\text { way of separating } \\
\text { them from the } \\
\text { surroundings, } \\
\text { open areas only } \\
\text { where technical } \\
\text { infrastructure } \\
\text { prevents different } \\
\text { use) }\end{array}$ & $\begin{array}{l}\text { Average: } \\
\text { (enhancement } \\
\text { of buildings' } \\
\text { aesthetical values } \\
\text { thanks to decorative } \\
\text { greenery, greenery } \\
\text { accompanying } \\
\text { single-family } \\
\text { buildings as a } \\
\text { way of separating } \\
\text { them from the } \\
\text { surroundings) }\end{array}$ \\
\hline Availability & $\begin{array}{c}\text { Good } \\
\text { (publicly available; } \\
\text { proximity of } \\
\text { parks located in } \\
\text { neighboring estates) }\end{array}$ & $\begin{array}{l}\text { Rather good } \\
\text { (publicly available } \\
\text { but some residents } \\
\text { may have difficulty } \\
\text { reaching it due to the } \\
\text { difference in altitude) }\end{array}$ & $\begin{array}{l}\text { Below average } \\
\text { (most of greenery } \\
\text { not publicly } \\
\text { available) }\end{array}$ & $\begin{array}{c}\text { Rather good } \\
\text { (publicly available) }\end{array}$ \\
\hline
\end{tabular}

Table 3. Possible solutions of the observed problems

\section{Estate}

Piaski \& Osiedle Tysiąclecia

\section{Słoneczny Stok}

Nowe Miasto

Zielone Wzgórza

\section{Suggestions}

1. Preservation of existing greenery - preventing the land from being used for other functions

2. Construction of diverse associated infrastructure

1. Introduction of more high greenery

2. Creating new green areas in the centre of the estate

1. Renovation of green area

2. Introduction of more high greenery. Should it be impossible due to the presence of technical infrastructure - replacing lawns with flower meadows

3. Creating new green areas in the centre of the estate

1. Introduction of more high greenery

2. Creating a recreational area accessible to all residents

\section{Summary}

Green areas play an important role in shaping the city's image. They significantly improve the aesthetics of the environment, shape the microclimate and protect against noise and pollution. In addition, they constitute the most accessible recreation areas for residents and create conditions for social integration. It is therefore necessary to develop favorable greenery solutions in the spatial planning process and to identify specific areas of greenery as important for the city in order to protect them from improper and uncontrolled investment in the future.

It is worth remembering that not all types of greenery perform identical functions. Therefore, reducing the issue of greenery in the planning process to a certain percentage of biologically active surfaces is highly disadvantageous. The local plans should contain more detailed entries. For example, more land ought to be 
allocated for greenery and the existing stand shall be preserved. Landscape architects should play a greater role in the process of creating new estates, so that the buildings are harmoniously incorporated into their surroundings and accompanied by carefully selected vegetation that would enhance their features. The solutions such as green roofs or green walls can be employed. Although they will never completely replace 'classic' green spaces, their presence is also beneficial thus highly desirable.

Considering the condition of the greenery in the examined housing estates in Białystok, it can be stated that its potential is under-utilised. The existing green areas are well-kept and pleasing to the eye, but it should be remembered that the aesthetic function should not be the only one they perform. The analyzed estates lack easily accessible recreational spaces for residents and larger green areas within their borders, such as parks. In addition, shortage of high greenery can be seen in three out of four analyzed estates. Hence the solutions:

- Prevention of turning the green areas into parking lots;

- Maintenance of existing greenery and ensuring they perform their functions well;

- Increasing the share of high greenery;

- Creation of recreational areas that would be accessible to all residents of a given housing estate. If it is impossible to attain a larger area for the park, it is postulated to create several pocket parks, evenly distributed throughout the estate.

\section{Literature}

[1] Asani A., 2007, Miejsce i znaczenie terenów zielonych, Zeszyty Naukowe, Inżynieria Środowiska nr 135, Uniwersytet Zielonogórski, Oficyna Wydawnicza Uniwersytetu Zielonogórskiego, Zielona Góra

[2] Banaszak J., Izdebska B., 1995, Ekologiczny aspekt lokalizacji i jakości zieleni na przykładzie miasta Bydgoszczy, Studia Przyrodnicze, 1995, Zeszyt 11, Wydawnictwo Uczelniane Wyższej Szkoły Pedagogicznej w Bydgoszczy, Bydgoszcz

[3] Degórska B., 2004, Planowanie terenów otwartych w nowej przestrzeni miejskiej (na przykładzie strefy podmiejskiej Warszawy), [w:] red. Kistowski M., Studia ekologiczno-krajobrazowe w programowaniu rozwoju równoważonego. Przegląd polskich doświadczeń u progu integracji z Unią Europejską, s. 142, Uniwersytet Gdański, Bogucki Wydawnictwo Naukowe, Gdańsk

[4] Gehl J., 2009, Życie między budynkami. Użytkowanie przestrzeni publicznych, Wydawnictwo RAM, Kraków

[5] Główny Urząd Statystyczny, http://stat.gov.pl [dostęp 11.02.2019 r.]

[6] Godzina P., 2015, Tereny zieleni publicznej w kontekście zrównoważonego rozwoju miasta, „Prace Geograficzne”, z. 141, 57-72, Instytut Geografii i Gospodarki Przestrzennej UJ, Kraków

[7] Kłopotowski M., 2016, Zieleń na terenie wielorodzinnych zespołów mieszkaniowych w Białymstoku, [w:] red. Gawryluk D., Kłopotowski M., O terenach zieleni we współczesnym mieście, Agencja Wydawnicza Ekopress, Białystok, str. 83 i 99

[8] Korwel-Lejkowska B., Topa E., 2017, Dostępność parków miejskich jako elementów zielonej infrastruktury w Gdańsku, Rozwój Regionalny i Polityka Regionalna 37, s. 63-75, Gdańsk

[9] Mierzejewska L., 2004, Przyrodnicze aspekty rozwoju zrównoważonego miast, Bogucki Wydawnictwo Naukowe, Poznań

[10] Oleksiejuk E., 2005, Rola i funkcje zieleni w mieście, Polskie Zrzeszenie Inżynierów i Techników Sanitarnych, Toruń

[11] red. Berghöfer A., 2001, Poradnik TEEB dla miast: usługi ekosystemów w gospodarce miejskiej, Fundacja Sendzimira, Kraków

[12] The New Charter of Athens, 2003

[13] Sutkowska E., 2006, Wspótczesny kształt i znaczenie zieleni miejskiej jako zielonej przestrzeni publicznej w strukturze miasta - przestrzeń dla kreacji, Teka Komisji Architektury, Urbanistyki i Studiów Krajobrazowych, Lublin

[14] Zachariasz A., 2006, Zieleń jako wspótczesny czynnik miastotwórczy ze szczególnym uwzględnieniem roli parków publicznych,Wydawnictwo Politechniki Krakowskiej, Kraków

\section{Websites}

[15] GDOŚ, Pomniki przyrody, http://crfop.gdos.gov.pl/CRFOP/widok/viewpomnikprzyrody.jsf?fop=PL.ZIPOP.1393. PP.2061011.7021 [dostęp 27.04.2019 r.]

[16] Białystok Online, Jak zmienit się Biatystok od lat 70. XX w., http://www.bialystokonline.pl/jak-zmienil-sie-bialystok-od-lat-70-xx-w-unikalne-zdjecia-z-lotu-ptaka,artykul,69379,1,1.html [dostęp 12.02.2019 r.]

[17] SM Piaski, Historia, http://smpiaski.pl/historia/ [dostęp 30.05.2019 r.] 